Animal Health Research Institute, Zagazig Branch.

\title{
SOME STUDIES ON ORNITHOBACTERIUM RHINOTRACHEALE INFECTION IN BROILER FLOCKS AT SHARKIA GOVERNORATE
}

(With 5 Tables)

By

\section{H.I.R. EL-BANNA; E.A. MASOUD and M.K. RIZK*}

*Animal Health Research Institute, Mansoura Branch

(Received at 18/9/2008)

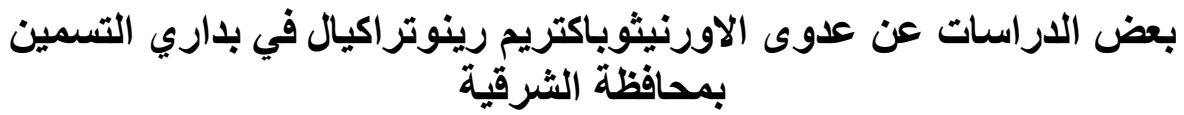

\section{حلمي إبراهيم رجب البنا ، السبل السعبل مسعود ، مدحت كمال رزق}

تم أخذ عينات من 200 طائر تعاني من أمر اض تتفسية من بعض المزارع في محافظة

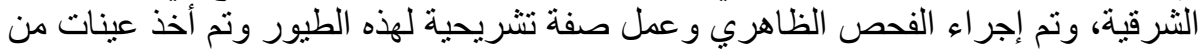

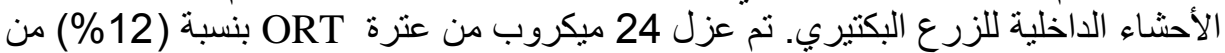

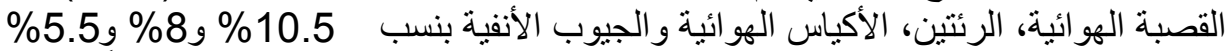

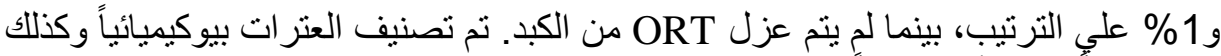

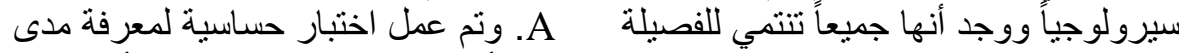
حساسية العتر ات المعزولة للمضادات الحيوية ووجد أن جميع العتر ات حساسة للأموكسيسيلين

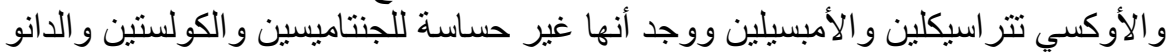
فلوكساسين. وتم عمل العدوى الصناعية بالعترات المعزولة بالرش في دجاج تسمين عمر 3

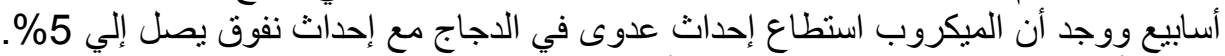

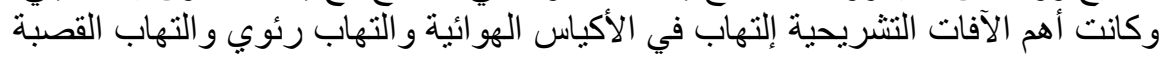
الهو ائية.

\section{SUMMARY}

The present study was carried out on 200 broiler chickens which had respiratory troubles on different farms of different districts at Sharkia Governorate, to throw a spot light on the clinical and microbiological investigations as well as prevalence rate of ORT infection in broiler flocks. Bacteriological examination revealed that 24 isolates $(12 \%)$ of ORT were isolated from the examined birds. ORT was isolated from trachea, lungs, air sacs and sinuses in a percentage of $10.5 \%, 8 \%, 5.5 \%$ and $1 \%$ respectively. No ORT was isolated from liver. Serotyping of 
ORT using AGPT proved that all the isolates were belonged to serotype A. Antibiogram studies showed that all the isolates were highly sensitive to Amoxycillin, Ampicillin, Oxytetracyclin, and resistant to Gentamicin, Danofloxacin and colistin. Experimental infection with ORT evoked respiratory signs with mortality rate reached to $5 \%$.

Key words: Ornithobacterium rhinotracheale, broiler, respiratory troubles.

\section{INTRODUCTION}

Respiratory diseases due to infectious agents are an important problem in the broiler chicken industry (Turan and Akcadag, 2003). Ornithobacterium rhinotracheale (ORT) is a pathogenic agent causing respiratory diseases especially in chickens and turkeys (Hadimli and Erganis, 2004 and Kaukonen et al., 2004). Ornithobacterium rhinotracheale is a recent described species of bacterium associated with respiratory diseases, growth retardation, mortality and decreased egg production in chickens and turkeys. Pneumonia, pleuritis and air sacculitis characterize the infection (Canal et al., 2005 and Veen et al., 2005).

Ornithobacterium rhinotracheale (ORT) has been firstly isolated from broiler chickens by DuPreez (1991). Recently, Hafez (2001) isolated ORT from ducks, goose, ostrich, pheasants, pigeons, quails, rook and turkeys.

In many countries of the worlds, ORT has been incriminated as a possible additional causative agent in respiratory disease complex in poultry. The organism cause substantial financial losses due to high rates of contamination up to $50 \%$ in slaughtered affected flocks (Charlton et al., 1993; Hinz et al., 1994; Dudouyt et al., 1995; Back et al., 1997; Hafez and Sting, 1999 and Van Empel, 1999).

\section{MATERIALS and METHODS}

\section{(1) Samples:}

A total of 200 diseased and freshly dead birds suffering from respiratory troubles were collected from different farms of different districts at Sharkia Governorate. The examined birds were subjected to clinical signs and postmortem examination.

\section{(2) Isolation and identification:}


Loopfuls from trachea, lungs, air sacs, sinuses and liver were inoculated into defibrinated $10 \%$ sheep blood agar media containing 10ug gentamicin sulphate/ml blood agar (Back et al., 1996 and Rahimi and Banani, 2007) and incubated at $37^{\circ} \mathrm{C}$ for 48 hours under $7.5-10 \%$ $\mathrm{Co}_{2}$ tension by using gas bags (Oxoid) in candle jar according to Vandamme et al. (1994) and examined for suspected ORT colonies.

The obtained pure cultures of ORT were identified biochemically according to Hafez et al. (1993). The isolates were serotyped by using agar gel precipitation test (AGPT) according to Van Empel, (1997).

\section{(3) Sensitivity test:}

It was carried out according to the technique described by Back et al. (1997).

\section{(4) Pathogenicity test:}

This experiment was done to study the effect of ORT isolates on three weeks old broiler chickens.

One hundred and fifty, one day old broilers obtained from Al-Brmawy Company. Ten of them sacrificed and were subjected to postmortem and bacteriological examination. These birds were free from infection with ORT. The remaining 140 chicks were grouped into four equal groups (A, B, C and D).

All birds were vaccinated with Lasota ND vaccine. First group (A) remained as control not infected and not treated while groups $(\mathrm{B}, \mathrm{C}$ and D) infected with ORT. The Group (B) was remained not treated but group (C) was treated with Amoxycillin 10mg/kg b.wt. for 3 days. Group (D) was treated with Amoxycillin $10 \mathrm{mg} / \mathrm{kg}$ b.wt. for 5 successive days. The dose of ORT was $100 \mathrm{ml}$ of cultured brain heart infusion broth (BHI), each $\mathrm{ml}$ of culture contain $\times 10^{9}$ c.f.u. The ORT was inoculated by coarse spray (Van Empel et al., 1996).

Birds were kept under observation for 4 weeks post infection. Clinical signs, postmortem lesions and reisolation trials and mortality were recorded.

\section{RESULTS}


Table 1: Results of isolation of ORT from naturally infected chicken in different farms at Sharkia Governorate.

\begin{tabular}{|c|l|c|c|c|c|c|}
\hline \multirow{2}{*}{$\begin{array}{c}\text { Case } \\
\text { No. }\end{array}$} & Districts & \multirow{2}{*}{$\begin{array}{c}\text { Total number } \\
\text { of birds in } \\
\text { farm }\end{array}$} & \multirow{2}{*}{$\begin{array}{c}\text { No. of } \\
\text { examined } \\
\text { birds }\end{array}$} & \multicolumn{2}{|c|}{$\begin{array}{c}\text { Result of } \\
\text { examined birds for }\end{array}$} & $\begin{array}{c}\text { Result of } \\
\text { bacterial } \\
\text { isolation for } \\
\text { ORT }\end{array}$ \\
\hline 1 & Hehia & 20000 & 8 & 2 & 25 & +ve \\
\hline 2 & Al-Hussaynia & 10000 & 12 & 1 & 8.33 & +ve \\
\hline 3 & Kanayat & 15000 & 15 & 3 & 20 & +ve \\
\hline 4 & El-Salhia & 25000 & 15 & 1 & 6.67 & +ve \\
\hline 5 & Abo-Kabier & 22000 & 5 & 2 & 40 & +ve \\
\hline 6 & Belbis & 30000 & 30 & 1 & 3.33 & +ve \\
\hline 7 & Dearb Negm & 10000 & 22 & 2 & 9.09 & +ve \\
\hline 8 & Menia El- Kamh & 10000 & 24 & 3 & 12.5 & +ve \\
\hline 9 & Abo Hamad & 10000 & 22 & 4 & 18.18 & +ve \\
\hline 10 & Abo Hamad & 15000 & 14 & 3 & 21.43 & +ve \\
\hline 11 & Belbis & 18000 & 13 & 1 & 7.69 & +ve \\
\hline 12 & Fakous & 12000 & 20 & 1 & 5 & +ve \\
\hline & Total & 197000 & 200 & 24 & 12 & + \\
\hline
\end{tabular}

Table 2: Biochemical character for isolated ORT.

\begin{tabular}{|l|c|}
\hline \multicolumn{1}{|c|}{ Biochemical test } & Reaction \\
\hline Oxidase & + \\
\hline Catalase & - \\
\hline Urease & + - \\
\hline Indole & - \\
\hline Nitrate reduction & - \\
\hline Methyl red & - \\
\hline Voges proskauer & - \\
\hline Citrate utilization & + \\
\hline Sugar fermentation & + \\
\hline Glucose & + \\
\hline Sucrose & - \\
\hline Maltose & - \\
\hline Lactose & + \\
\hline Fructose & + \\
\hline Galactose & + \\
\hline
\end{tabular}

Table 3: Isolation of ORT from internal organs of naturally infected birds. 
Assiut Vet. Med. J. Vol. 54 No. 119 October 2008

\begin{tabular}{|c|c|c|c|c|c|c|}
\hline \multirow{2}{*}{ Flock No. } & Number of & \multicolumn{5}{|c|}{ Isolation of the internal organs } \\
\cline { 3 - 7 } & +ve cases & Trachea & Lungs & Air sacs & Sinuses & Liver \\
\hline 1 & 2 & 2 & 2 & 1 & 1 & - \\
\hline 2 & 1 & 1 & 1 & 1 & 1 & - \\
\hline 3 & 3 & 3 & 2 & 2 & - & - \\
\hline 4 & 1 & 1 & 1 & - & - & - \\
\hline 5 & 2 & 1 & 1 & - & - & - \\
\hline 6 & 1 & 1 & 1 & 1 & - & - \\
\hline 7 & 2 & 2 & 1 & 1 & - & - \\
\hline 8 & 3 & 3 & 2 & 1 & - & - \\
\hline 9 & 4 & 3 & 2 & 1 & - & - \\
\hline 10 & 3 & 2 & 1 & 1 & - & - \\
\hline 11 & 1 & 1 & 1 & 1 & - & - \\
\hline 12 & 1 & 1 & 1 & 1 & - & - \\
\hline \multirow{2}{*}{ Total } & 24 & 21 & 16 & 11 & 2 & - \\
\cline { 2 - 7 } & $12 \%$ & $10.5 \%$ & $8 \%$ & $5.5 \%$ & $1 \%$ & $0 \%$ \\
\hline
\end{tabular}

Table 4: Result of in vitro sensitivity test of ORT isolates to different antimicrobial agents.

\begin{tabular}{|c|l|c|c|c|}
\hline No & Antibiotic disc & Discpotancy & Standard sensitivity & \\
\hline 1 & Amoxicillin & $25 \mathrm{ug}$ & $>13<16$ & +++ \\
\hline 2 & Oxytetracycline & $30 \mathrm{ug}$ & $>13<16$ & +++ \\
\hline 3 & Ampicillin & $10 \mathrm{ug}$ & $>11<13$ & +++ \\
\hline 4 & Ciprofloxacin & $10 \mathrm{ug}$ & $>13<15$ & ++ \\
\hline 5 & Streptomycin & $25 \mathrm{ug}$ & $>15<18$ & ++ \\
\hline 6 & Enrofloxacine & $54 \mathrm{ug}$ & $>15<18$ & ++ \\
\hline 7 & Neomycin & $19 \mathrm{ug}$ & $>13<16$ & - \\
\hline 8 & Spectinomycin & $10 \mathrm{ug}$ & $>13<15$ & - \\
\hline 9 & Gentamicin & $10 \mathrm{ug}$ & $>15<18$ & - \\
\hline 10 & Colistin & $10 \mathrm{ug}$ & $>13<16$ & - \\
\hline 11 & Danofloxacin & $5 \mathrm{ug}$ & $>11<13$ & - \\
\hline
\end{tabular}

Table 5: Experimental infection of 3 weeks-old broiler chickens with ORT isolates

\begin{tabular}{|c|c|c|c|c|c|c|c|}
\hline Group & $\begin{array}{c}\text { No. of } \\
\text { birds }\end{array}$ & $\begin{array}{c}\text { Infected } \\
\text { with } \\
\text { ORT }\end{array}$ & $\begin{array}{c}\text { Treatment } \\
\text { with } \\
\text { Amox }\end{array}$ & P.M. lesion & $\begin{array}{c}\text { Morbidity } \\
\text { rate }\end{array}$ & $\begin{array}{c}\text { Mortality } \\
\text { rate }\end{array}$ & $\begin{array}{c}\text { Reisolation } \\
\text { of ORT }\end{array}$ \\
\hline (A) & 35 & - & - & - & - & - & - \\
\hline (B) & 35 & $+\mathrm{ve}$ & - & $\begin{array}{l}\text { Pneumonia } \\
\text { Exudate in air sacs } \\
\text { Severe congestion } \\
\text { of trachea }\end{array}$ & $57 \%$ & $5 \%$ & $4 / 5$ \\
\hline (C) & 35 & $+\mathrm{ve}$ & $+\mathrm{ve}$ & $\begin{array}{l}\text { Pneumonia } \\
\text { Exudate in air sacs }\end{array}$ & $22 \%$ & $1 \%$ & $1 / 5$ \\
\hline (D) & 35 & $+\mathrm{ve}$ & $+\mathrm{ve}$ & Pneumonia & $10 \%$ & $0 \%$ & $1 / 5$ \\
\hline
\end{tabular}

DISCUSSION 
Natural infection of ORT in chickens at 4 weeks which was suffering from relatively mild respiratory signs (nasal exudates, sneezing, wetting of eyes, swelling of infraorbital sinus, retarded growth) accompanied by increased mortalities. The course of the disease was about 10- 14 days.

These finding were concurrent with findings of Van Beek et al. (1994); Sakai et al. (2000) and Heyla et al. (2005).

The main postmortem lesions in examined birds were congestion of respiratory passage and trachea, pneumonia, exudate in the air sacs, predominantly in the abdominal air sacs were the most striking feature. Similar findings were observed by Hafez et al. (1993) and Abd ElGhany Wafaa, (2000).

The isolation of 24 (12\%) isolates of ORT from 200 diseased and freshly dead chickens were collected from different farms of different districts at Sharkia Governorate were reflected their wide distribution through out these province (Table 1).

The distribution of ORT in internal organs showed that the highest incidence were observed in trachea (10.5\%), lungs $(8 \%)$, air sac $(5.5 \%)$, sinuses $(1 \%)$ and liver $(0 \%)$ (Table 3$)$. These findings were supported with the results reported by Chin (1996); Cauwerls et al. (2002) and El-Gohary and Sultan (2002).

Morphologically, the ORT colonies were observed on $10 \%$ sheep blood agar as non-haemolytic, non-pigmented grayish white colonies.

Microscopical examination of ORT colonies, stained with Gram stain revealed highly pleomorphic Gram negative rods, non-motile, nonspore former and non-capsulated. These findings inconformity with those obtained by Hafez et al. (1993); Van Empel et al. (1996) and Hanan et al. (2008).

The biochemical reaction of the ORT isolates in Table (2). These findings agree with those described by Charlton et al. (1993); Hinz, et al. (1994); De Rosa et al. (1996) and El-Gohary et al. (1998).

Serotyping of 24 isolates of ORT using agar gel precipitation test with specific antisera against 18 ORT serotypes (A-R) revealed that all tested isolates were belonged to serotype A. These findings were similar to the previous results recorded by Hafez, (1996); El-Gohary and Awaad, (1998) and Abd El-Ghany, Wafaa (2000).

The result of sensitivity test for ORT isolates against antimicrobial agents, by using disc diffusion technique (Table 4) revealed that the isolates were sensitive to Amoxycillin, Oxytetracycline and Ampicillin while were variably to Ciprofloxacine, Streptomycin and 
Enrofloxacine and resistant to Neomycin, Spectinomycin, Gentamicin, Colistin and Danofloxacin. These result agreed partially with those described by Hinz et al. (1994).

Experimental infection with ORT are given in Table (5). Birds in group (B) "infected with ORT and not treated", the ORT was able to reproduce the respiratory disease as the same characteristics as seen in the natural outbreak and the mortality was 5\% and morbidity rat was 57\%. The birds in group (C) "infected with ORT and treated with Amoxycillin for 3 days", the ORT was cause light respiratory disease and mortality rate was $1 \%$ and morbidity rate was $22 \%$. While the birds in group (D), the mortality rate was $0.0 \%$ and morbidity rate was $10 \%$. Similar results observed by Hinz et al. (1994).

The result of treatment of experimentally infected broiler revealed that the treatment with Amoxycillin $10 \mathrm{mg} / \mathrm{kg}$ b.wt. for 5 days decreased the mortality and morbidity rates than those treated with Amoxycillin $10 \mathrm{mg} / \mathrm{kg}$ b. wt. for 3 days. Reisolation rate of ORT from experimentally infected and not treated broilers was $80 \%$ but $20 \%$ reisolation rate was recorded in infected and treated birds. These results were in agreement with those obtained by Hafez et al. (1993) and Awaad et al. (2002).

It is concluded that the ORT infection are incorporated in complicated respiratory infection and the utmost need for use of sensitive antibiotic for control measures considered an important direction to avoid loss of body weight, respiratory signs and economic losses.

\section{REFERENCES}

Abd El-Ghany, Wafaa (2000): Epizootiological investigation on O. rhinotracheale "ORT" in chicken broilers. M.V.Sc. Thesis, Fac. of Vet. Med., Cairo Univ.

Awaad, M.H.H.; El-Gahary, A.A. and Sultan, H.A. (2002): Effect of volatile oils "Mentofen (B) on concomitant infection with $O$. rhinotrachcale "ORT" and viscerotropic velogenic Newcastle disease virus (VVNDV) in broiler chickens. In the XII International Congress of the World Veterinary Poultry Association, Cairo, Egypt, January $28^{\text {th }}, 2002$.

Back, A.; Nagaraja, K.V. and Halvorson, D. (1996): Preliminary studies on $O$. rhinotracheale. In Proceedings of the turkey ORT symposium, September 4-6 Minneapolis, Minnesota, pp. 29-31. 
Back, A.; Sj \& phanie, S.; Rajashekara, G.; Halvorson, D. and Nagaraga, K. (1997): Antimicrobial sensitivity of $O$. rhinotracheale isolated from different geographic locations. $48^{\text {th }}$ North Central Avian Disease Conference. 22-24.

Canal, C.W.; Leao, J.A.; Rocha, S.L.S.; Macagnan, M.; Lima-Rosa, C.A.V.; Oliveira, S.D. and Back, A. (2005): Isolation and characterization of $\mathrm{O}$. rhinotracheale from chickens in Brazil. Research in Veterinary Science. 78 (3): 225-230.

Cauwerls, K.; Deherdt, P.; Vervloesem, J. and Pucatella, R. (2002): Epidemiology of $O$. rhinotracheale infection in broilers in Belgium. In the XII International Congress of the World Veterinary Poultry Association, Cairo, Egypt, January, $28^{\text {th }}$.

Charlton, B.; Channing, S.; Santagio, S.; Bickford, A.; Cardona, C.; Chin, R.; Copper, G.; Droual, R.; Jeffery, J.; Mateyer, C.; Shivaprasad, H. and Walker, R. (1993): Preliminary characterization of a pleomorphic Gram-negative rode associated with avian respiratory disease. J. of Veterinary diagnostic Investigation. 5: 47-51.

Chin, R. (1996): O. rhinotracheale infection in turkeys. Hofman Roche. $2^{\text {nd }}$ International Turkey Advisory Board Conference. Raleigh, North Carolina.

De Rosa, M.; Druoal, R.; Chin, R.; Shivaprosad, H. and Walker, R. (1996): Or. Rhinotracheale infection in turkey breeder. Avian Diseases, 40: 865-874.

Dudouyt, J.; Leorat, L.; Van Emple, P.; Gradin, Y. and Celine, D. (1995): Isolement d'un nouvel pathogene chez la dinde: O. rhinotracheale. Journees de la Recherche Avicole. Angers, France, Mars, 1995.

DuPreez, C.F. (1991): Current status on the role of O. rhinotracheale $(O R T)$ in respiratory disease complexes in poultry. Arch. Geflugelk, 60 (5): 208-211.

El-Ghohary, A.A. and Awaad, M.H.H. (1998): Concomitant $O$. rhinotracheale (ORT) and E. coli infection in broilers. Veterinary Medical Journal Giza. 46 (1): 67-75.

El-Gohary, A. and Sultan, H. (2002): Sero-epidemiological studies on $O$. rhinotracheale infections in chickens and turkey flocks in proceedings XII International Congress of the World Veterinary Poultry Association Sept. 17-21 Cairo-Egypt. 
El-Gohary, A.A.; Sultan, H.A. and Hafez, H.M. (1998): Isolation of $O$. rhinotracheale (ORT) and Pasteruella haemolytica from commercial layer chicken in proceeding $5^{\text {th }}$ In Proceeding of the $16^{\text {th }}$ meeting of the European Scarcity of Veterinary Pathology, Lillehammer, pp. 81.

Hadimli, H.H. and Erganis, O. (2004): The infection and diagnosis of O. rhinotracheale. Veteriner Bilimleri Dergisi. 20 (2): 73-78.

Hafez, H.M. (1996): Current status on the role of O. rhinotracheale (ORT) in respiratory disease complexes in poultry. Archiev. Fur Gelfugelkunde, 61: 208-211.

Hafez, H.M. (2001): Emerging and re-emerging bacterial diseases $\mathrm{m}$ poultry: a review. Wiener Tierarztliche Monatsschrift; 90 (7): 174-181.

Hafez, H.M. and Sting, R. (1999): Comparative investigation of different O. rhinotracheale (ORT) isolates. Avian Diseases, 43: 1-7.

Hafez, H.M.; Kruse, W.; Emele, J. and Sting, R. (1993): Eine Atemwegsinfettion ber mostputen durch pastreurella-ahnliche erreger. Klinik, Diagnostic Undtherapie. In The proceedings of The International Conference on Poultry Diseases, Potsdam, pp. 112.

Hanan, M.F. Addien; Mohamed, H. Awaad; Mohsen El-Demerdash and Wael Abd El-Latif (2008): Studies on Ornithobacterium Rhinotracheale infection in chickens. $9^{\text {th }}$ Vet. Med. Zag. Conference (20-22 Auguset 2008) Port-Said. Pp. 446-457.

Heyla, S.; Rkylmaz, T. and Osmdn, K. (2005): Detection of antibodies produced against $O$. rhinotracheale and bordetella avium by enzyme-linked immunosorbent Assay in Hens and Turkeys in Aydan Province, Turkey Turk. J. Vet. Anim. Sci. 29: 897-902.

Hinz, K.H.; Blome, C. and Ryll, M. (1994): Acute exudative pneumonia and air sacculitis associated with $O$. rhinotracheale in turkeys. Veterinary Record. 135 (10): 233-234.

Kaukonen, E.; Raunio Saarnisto, M. and Perko-Makela, P. (2004):

O. rhinotracheale respiratory infections in poultry- a literature review. Suomen Elainlaakarilehti. 110 (10): 487-495.

Rahimi, M. and Banani (2007): Isolation of ORT from chickens of broiler farm in West of Iran. Iranian Journal of Veterinary Research, Universt. of Shiraz, 8 (4): 21.

Sakai, E.; Takuyama, Y.; Nomaka, F.; Ohishi, S.; Ishikawa, Y.; Tanaka, M. and Taaneno, A. (2000): O. rhinotracheale infection in 
Japan: Preliminary investigations. Veterinary Record (146): 502-503.

Turan, N. and Akeadag, B. (2003): O. rhinotracheale infection in a commercial broiler flock. Turk- Veterinerlik Hayvanclk Dergisi. 27 (6): 1447-1450.

Van Beek, P.; Van Empel, P.C.M.; Van den Bosh, G.; Storm, P.; Bongers, J. and Dupreez, J. (1994): Respiratory problems growth retardation and arthritis in turkeys and broilers caused by a pasteurella-like organism $O$. rhinotracheale or Taxo 28. Tijdschrift voor Diergeneeskunde, 119: 99-101.

Van Empel, P.C.M. (1997): O. rhinotracheale: An Update. In the Proceedings of the $2^{\text {nd }}$ Meeting of the fachgruppe Geflugelkrankheiten der Deutsche Veterinary- Medizinische. Gesellschaft. Hannover, pp. 20-25.

Van Empel, P.C.M. (1999): O. rhinotracheale. Avian Pathology, 28: 217-227.

Van Empel, P.C.M.; Van den Bosch, H.; Goovaorts, D. and Storm, P. (1996): Experimental infection in turkeys and chickens with O. rhinotracheale. Avian Diseases. 40: 858-864.

Van Empel, P.C.M.; Van den Bosch, H.; Loeffen, P. and Storm, P. (1997): Identification and serotyping of $O$. rhinotracheale. Journal of Clinical Microbiology, 35: 418-421.

Vandamme, P.; Segars, P.; Vancaney, M.; Van Hover, K.; Mutters, R.; Hommez, J.; Dewirst, F.; Paster, B.; Kersters, K.; Falsen, E.; Devrieze, L.; Bisgaard, M.; Hinz, K.H. and Monmheim, W. (1994): Description of O. rhinotrachesle gen. Nov.-Sept. Isolated from avian respiratory tract. International Journal of Systematic Bacteriology. 44: 24-37.

Veen, L. Van; Nieuwenhuizen, J.; Mekkes, D.; Vrijenhoek, M. and Empel, P. Van (2005): Diagnosis and incidence of $O$. rhinotracheale infection in commercial broiler chickens at slaughter. Veterinary Recoed. 156 (10): 315-317. 